\title{
Jurnal Pendidikan Bahasa dan Sastra
}

\author{
p-ISSN 1412-0712 I e-ISSN 2527-8312 \\ Volume 16, Nomor 1, April 2016, hlm.1-121
}

\section{DAFTAR ISI}

The Antonym of Lexeme Using the Affixation "Me-Kan": Morphosemantics Analysis

Muhammad Yunus Anis, \& Kundharu Saddhono, Sebelas Maret University

Writing Grammatical Sentences: Voices of Indonesian Undergraduates in EFL

Classrooms

Yustinus Calvin Gai Mali, Universitas Kristen Satya Wacana

Kalimat Pengandaian Bahasa Jepang: Kajian Sintaktis dan Semantis

Dedi Sutedi, \& Susi Widianti, Universitas Pendidikan Indonesia

Pemerolehan Sintaksis (B1) Bahasa Sasak pada Anak Usia 4-6 tahun di Lombok Timur Melalui Permainan Tradisional

Mushaitir, Universitas Mataram

English Writing Skill Analysis of First Year Indonesian Tertiary Students in a University in Bandung

Dian Yuliana, Ernie D. A. Imperiani, \& Eri Kurniawan, Universitas Pendidikan Indonesia

Fonologi Bahasa Abun di Kabupaten Tambrauw Provinsi Papua Barat

Antonius Maturbongs, \& Asmabuasappe, Balai Bahasa Provinsi Papua

Why is There Code Switching in EFL Classsroom?: A Case Study in a Vocational School In Cimahi West-Java

Diana Nur Fathimah, Universitas Pendidikan Indonesia

Pengaruh Kemampuan Kosakata dan Struktur Kalimat Terhadap Kemampuan

Menulis Paragraf Deskripsi Siswa SMA

Munirah, \& Hardian, Universitas Muhammadiyah Makassar

Analyzing Audience Awareness in Academic Writing Among Undergraduates

Noor Hanim Rahmat, Universiti Teknologi Mara, Malaysia

Analisis Makna Kanyoku yang Berkaitan dengan Warna:

Kajian Linguistik Kognitif

Widi Sekarsari , \& Nuria Haristiani, Universitas Pendidikan Indonesia

Pengaruh Input Bahasa Orang Tua terhadap Kompleksitas Bahasa Anak: Studi Kasus pada Anak Usia 5 tahun melalui Interactive Shared Reading

Hanna Sundari, Universitas Indraprasta PGRI 


\title{
THE ANTONYM OF LEXEME USING THE AFFIXATION 'ME-KAN': MORPHOSEMANTICS ANALYSIS
}

\author{
Muhammad Yunus Anis, \& Kundharu Saddhono \\ Sebelas Maret University, Surakarta \\ E-mail: yunus_678@staff.uns.ac.id
}

\begin{abstract}
This research deals with morphosemantic analysis of lexemes. The main source of data in this research was taken from the Arabic-Indonesian dictionary, Al-Munawwir, with the primary focus on lexemes using the affixation of "me-kan". The lexemes with affixation "me-kan" can be compared in the Arabic language using the dominant measure or pattern (wazan). This research adopts a qualitative descriptive analysis, employing the distributional approach and the technique of dividing units of language, as well as the technique of marker. The study shows that the lexemes using affixation "me-kan" in Indonesian have similarities with the wazan fa-'a-la in Arabic. The affixation of "me-kan" is one of the forms of transitive verb in the Indonesian language, and wazan fa-'a-la in Arabic is a form of ta'diyyab (close meaning with the transitive form). Many lexemes using the affixation "me-kan" in Al-Munawwir Indonesian-Arabic dictionary were translated by the wazan fa-'a-la. This study indicates that there is a strong connection between the transitive form in Arabic and Indonesian, as indicated through the analysis of the aforementioned lexemes.
\end{abstract}

Keywords: antonym, lexeme using the affixation of "me-kan", morpho-semantics, and $\mathrm{Al}$ Munawwir Indonesian-Arabic dictionary.

\begin{abstract}
Abstrak
Sumber data dalam penelitian ini diambil dari kamus Al Munawwir versi Indonesia-Arab. Pembahasan antonim di dalam kamus tersebut masih terasa luas, belum mengerucut. Oleh sebab itulah peneliti akan memfokuskan pembahasan antonim hanya pada leksem yang mendapat imbuhan "me-kan". Selanjutnya leksem "me-kan" di dalam bahasa Indonesia ternyata memiliki padanan wazan(measure) di dalam bahasa Arab yang sangat dominan. Penelitian ini menggunakan model penelitian deskriptif kualitatif dengan menggunakan metode distribusional dan teknik bagi unsur langsung dan teknik pemarkah. Dengan memanfaatkan metode tersebut, maka penelitian secara masif di dalam kamus tersebut akan menemukan pemakaian wazan untuk leksem berimbuhan me-kan dengan frekuensi lebih banyak dibandingkan dengan wazan lainnya. Sehingga imbuhan me-kan pada bahasa Indonesia dapat ditemukan padanannya pada wazan bahasa Arab. Beberapa data berupa leksem berimbuhan "me-kan" di dalam kamus al munawwir versi Indonesia-Arab diterjemahkan dengan menggunakan wazan fa'ala. Imbuhan me-kan merupakan salah satu bentuk dari kata kerja transitif. Begitu pula waz̧an fa'ala di dalam bahasa Arab digunakan untuk "ta'diyyah" yang secara tidak langsung menyerupai dengan proses pembentukan kata kerja transitif di dalam bahasa Indonesia. Oleh sebab itulah wazan fa'ala menjadi wazan yang paling dominan pada pemberian makna leksem berimbuhan me-kan yang berfungsi sebagai kata kerja transitif.
\end{abstract}

Kata kunci: antonim, leksem yang menggunakan afiks me-kan, morfosemantik, kamus $\mathrm{Al}$ Munawwir Indonesia- Arab. 


\section{INTRODUCTION}

In a general way, structuralist linguistics had the opinion that the meaning being the focus of Semantics studies is not clear. It cannot be observed empirically such as grammatical units (morphology and syntax). Chomsky, the father of linguistics transformation, in his first book (1957) extremely did not discussed about meaning, but in second book (1965), he started to declare that Semantic is one of the main branches of grammar (the other components are syntax and phonology), and the meaning of the sentences actually was been determining by the Semantics element (Chaer, 2003:285).In its widest sense, the term structuralist has been used for many groups of linguists, including those of the Prague School, but most often it is used to refer to a group of American linguists such as Bloomfieldand Fries, who published mainly in the 1930s to 1950s. The work of these linguists was based on the theory of behaviorism and had a considerable influence on some language teaching methods.

Since, Chomsky has been doing the study of semantics deeply, the study of semantics as the part of linguistics study, begins to spread in wide range of linguistics discussion and research. Many attentions are being focused in Semantics study. Many kinds of Semantics theory had been appeared, thus the Semantics study is not being the periphery (perifer)again. This condition is also strengthened by the theory appeared by Ferdinand de Sausure, he has concluded that the sign of linguistics (signe linguistique) contain of two components, they are (1) signifian and (2) signifie, thus, the study of linguistics extremely needs to the study of semantics, linguistic study without semantic is nothing. Both of two studies cannot be separated.

One of the theories of Semantics getting the wide range of development is the theory about the "relation of meaning". In this theory of meaning relation will be elaborated about the synonym, antonym, polysemy, homonymy, hyponymy, ambiguity, and redundancy. To get the maximal result and focusing, this research just more focused to the one of form of meaning relation, antonym. The study about the opposition relation of meaning is very attractive in the linguistics study, it cannot be unwilling that all over languages in the world have the concept of the opposition relation of meaning, we cannot disclaim that all over languages in the world have the antonym theory. In Arabic language, we can describe it by 'aksi, in Chinese language we can describe the antonym with tao-fan, in France language, we can describe it with contraire, in Germany language: gegensatr, in Hungarian language: ellentet, the last, in the Turkey language: karsi (Cruse, 1986:197). In this research will be elaborated as for the problematic of lexeme using the affixation of "me-kan" in Indonesian language especially in the pair of antonym in parallel line with the figuration of the measure (wazan) or ta'diyyah pattern (transitive Arabic verbs pattern). To know the pair of antonym in this research, we will give some example as follow in the table 1.

\section{Table 1: The List of Antonym in Arabic and Indonesian Language}

\begin{tabular}{|c|c|c|c|c|}
\hline $\begin{array}{l}\text { The main } \\
\text { Antonym in } \\
\text { Indonesian } \\
\text { language } \\
\text { (1) }\end{array}$ & $\begin{array}{l}\text { Lexeme using the } \\
\text { affixation of "ME- } \\
\text { KAN" } \\
\text { (2) }\end{array}$ & $\begin{array}{l}\text { Antonym in } \\
\text { Arabic } \\
\text { Language } \\
\text { (3) }\end{array}$ & $\begin{array}{l}\text { The Meaning of the } \\
\text { opposite meaning of } \\
\text { Antonym in Arabic } \\
\text { Language } \\
\text { (4) }\end{array}$ & $\begin{array}{c}\text { The opposite } \\
\text { of Antonym } \\
\text { in Arabic } \\
\text { Language } \\
\text { (5) }\end{array}$ \\
\hline Bagus & Membaguskan & أُحسن - يُحسِنُ & Menjelekkan & 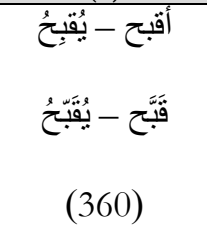 \\
\hline
\end{tabular}




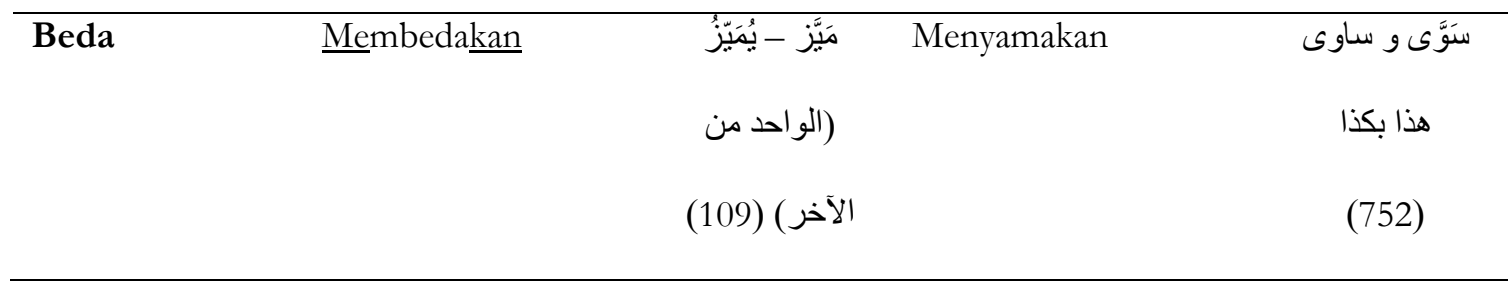

From the table 1, we can conclude that the word or lexeme "bagus" (column 1) in Indonesian language, after getting the affixation of "me-kan", becomes "membaguskan" (column 2) which has the same meaning in Arabic language with the word /achsana-yuchsinu/ (column 3), the opposite meaning of the word "membaguskan" in Indonesian language is "menjelekkan" (column 4) which has the same and equal meaning in Arabic language with the word /aqbacha-yuqbichu/ (column 5). The lexeme "menjelekkan" in Indonesia language refers to the lexeme JELEK in Indonesian language before getting the affixation "me-kan". Thus, the lexeme "menjelekkan" is transitive form. Transitive verb is a verb which takes an object, for example they saw the accident. A verb which takes an indirect and a direct object is known as ditransitive verb. The transitive verb in Arabic language usually is similarized with the term "al-fi'lu al-muta'adiy" (Richards, 2007:709). These transitive verbs in Arabic language and in Indonesian language have the same concept of relational meaning which is showing the opposite (antonym).

Antonym (tadhād - نضاد) is a word which is opposite in meaning to another word. For example, in English male and female, and big and small are antonyms. A distinction is sometimes made between pairs like male and female, and pairs like big and small, according to whether or not the words are gradable. A person who is not male must be female, but something which is not big is not necessarily small, it may be somewhere between the two sizes male and female are called complementaries (or ungradable antonyms); big and small are called gradable antonyms or a gradable pair. Some linguist use the term antonym to mean only gradable pairs (Becker, 1980; Fromkin and Rodman
1998; Lyons 1995; Chaer 2003;Husnaini 2005). Several studies on antonyms been done by linguists, both by researchers in Indonesia and other countries (Kostić, 2011, 2015; Anggraeni, 2015; Sasangka, 2004;Susanti, 2009; Ikrarini, 2012). The study shows that the study of antonym very interesting to be studied and analyzed from various perspectives.

Antonym or at-tadhad is a pair of words containing two or more words which have the meaning "reputed" as the opposite. It was confirmed as "reputed" because the characteristic of the opposite between two words in the antonym is relative. There are some words or lexemes which have the opposite meaning absolutely, such as (death $><$ live) and (daylight $><$ night). And also there are the opposite meaning which is not absolutely characterized, such as (far $><$ near), (reach $><$ poor), the meaning of the word "reach" is not absolutely "poor". The far distance is not always absolutely near. The word "tall" is not absolutely "low". These kinds of antonym has the relative character.

\section{METHODS}

The data in this research was taken from the corpus data from the Indonesian - Arabic language Al-Munawwir (2007) dictionary. The focusing analysis of antonym in the Arabic lexicon is very wide scope, so that we should specify the focus of antonym analysis in the Arabic - Indonesian language lexemes, words, and lexicons. The focusing analysis was pointing to the lexemes using the affixation of "ME-KAN". To get the maximal and professional result, we should get the focusing analysis. The method using in this research is distributional method or (Agih Method), (Sudaryanto, 1993:15) defined the distributional method as the method of language research which is having the tools 
of determining from the language itself. For example, if the people has determined that the nouns in Indonesian language is the word that can merge with the refuse word or negative words "bukan", but not using the word "tidak". So that, the people who determine the nouns in Indonesian language by merging with the word "bukan" is in the work of Agih Method or distributional approach in language researching. This method is also used to analyze the use of language in the Friday sermon (Saddhono, 2015)

In this research, the lexeme using the affixation "ME-KAN" will be analyzed using the distributional method or agih method. This method has the fundamental technique, we call it in Indonesian language (bagi unsur langsung or BUL), and it is the technique of language analysis to divide the language units directly to exploring the units forming the lexeme in Indonesian language. By using this technique, we can also know the parable form of lexeme using "MEKAN" in Indonesian language and its measure (wazan) in Arabic language. This technique was called "bagi unsur langsung" because in the first analysis language working, it divides the units of language into some parts or elements of certain language units. Finally, the divided units of language are determined as the main parts that directly forming and shaping the units of language. To complete the analysis, this research also used the technique reading the marker of unit language to exploring the original and authentic of lexeme using the affixation of "ME-KAN" in Indonesian language and its pattern and measure of lexeme using "ME-KAN" in Arabic language. Thus, the formal object of this research is antonym of lexeme using the affixation "ME-KAN". The material objects of this research are the antonym of lexemes in Al-Munawwir Indonesian - Arabic language Dictionary.

Depudyt (1997) has elaborated about the same theme with this research, he tried to give the approach about verbs in Arabic language, he had written about the case gender in Arabic language verbs, in his paper under the title Agent-Less Indirect Adjectival Forms in Egyptian and Arabic: The Case of JRRW N.F and MAF'UL LAHU 'for whom one acts. And also Schramm (1962), in wide range, has elaborated about the verb in Classical Arabic. Based on the vowel patterns elaborated by Schramm, this research tries to decide the rendering form of lexeme using the affixation "Me-Kan" into Arabic language which is using the transitive verb (ta'diyyah). To doing the semantic analysis in Arabic verbs, this research made the model from Kinberg (1987) under the title Causal and Adversative Meanings of the Particle lakkin in Arabic. Anis (2010) has elaborated about semantic analysis in Arabic verbs and Indonesian language, he tried to do his research about the verb "datang" in Indonesian language using the componential analysis, this research doing by Anis (2010, 2013, 2014,2015) becomes the prototype model of Arabic semantic and syntax analysis, especially about the fundamental sentences in Arabic language, such as jumlah ismiyyah (nominal sentences: $\mathrm{S}+\mathrm{V}+\mathrm{O}$ ) and jumlah fi'liyyah (verbal sentences: $\mathrm{V}+\mathrm{S}+\mathrm{O}$ ).

\section{FINDINGS AND DISCUSSION}

In the linguistics analysis, lexeme ( وحة (معجمية was defined as the smallest unit in the meaning system of a language that can be distinguished from other similar units. A lexeme is an abstract unit. It can occur in many different forms in actual spoken or written sentences, and is regarded as the same lexeme even when inflected. For example, in English, all inflected forms such as give, gives, given, giving, gave would belong to the one lexeme give. In Indonesia language, all inflected forms such as berbaik, berbaikan, berbaik-baikan, membaik, membaiki, membaikkan, terbaik, perbaikan, memperbaiki, pembaikan, kebaikan, sebaik would belong to the one lexeme BAIK. And also in Arabic language, all inflected forms such as /kātib/, /maktab/, /yaktub/, /kitabatan/, /maktub/, /inkataba/, /kattaba/ would belong to one lexeme ka-ta-ba. Similarly, such expressins as bury the hatcher, hammer and tongs, give up, and white paper would each be 
considered a single lexeme. In a dictionary, each lexeme merits a separate entry or subentry (Richards, 2007:388-389).

In Semantics study, the term of lexeme, can be defined as the unit of language having a meaning. One kind of the lexeme's form is a verb. Fundamentally, in Indonesian language and Arabic language, the verb can be divided into two forms, they are: (1) Transitive verb (الفعل المتعدي), a verb which takes an object, for example they saw the accident. We can also look in the Arabic language, such as: (عرفتهم) 'I recognized them'. In Indonesian language, the transitive verb immediately having the object after the verb, such as: membeli and mengobati. (2) Intransitive verb (فعل لازم), a verb which does not take an object, for example the children danced. In Arabic language, such as: 'she went out into the street', (بتظاتهرون) 'they demonstrate', ( تجرجي ' فيها الأنهار 'rivers run through it'. In Indonesian language, the intransitive verb is not having an object which participates in, such as menangis, menyanyi, and menari.

Substantively, the transitive verbs in Indonesian language can be divided into seven parts form of the verb, such as (1)The verb which does not have an affixation, for example: minta iqin, (2)The verb having an affixation (prefix ME), such as: menangkap pencopet and menembak burung, (3) The verb having an affixation (ME-KAN), such as: merapikan rambut, melepaskan tali, etc., (4)The verb having an affixation (MEMPER$\mathrm{KAN}$ ), for example: memperebutkan kekuasaan, (5) The verb using the affixation (ME-I), for example: mengawasi pekerja, (6) The verb having the affixation (MEMPERI), such as: memperbaiki sepeda, and (7) The verb using the affixation (MEMPER-), for example: memperdalam ilmu (Pamungkas, 1994:14-15).

The finding and discussion data in this research concluded that the lexeme using an affixation (me-kan) had been translated into Arabic language in $\mathrm{Al}$ Munawwir dictionary using the wazan (the measure) fa-'a-la (فعل). The function of affixation "me-kan" in Indonesian language is to form the transitive verbs. As also, the measure/ wazan fa-'a-la in Arabic language has the same function. The function of wazan fa'ala is for ta'diyyah, which is directly having the same function with the forming of transitive in Indonesian language. As the result of that conditions, wazan fa'ala becomes the dominant wazan/measure for translating and rendering the lexeme using the affixation "me-kan" in Indonesian language into Arabic language. Syekh Muhammad Ma'sum Ali in his fenomenal book of Arabic Morphology under the title "amtsilah at-tashrifiyyah" explained that the function of wazan fa'ala is used for ta'diyyah.

$$
\text { اللتعدية نحو: فرّ ح زيدٌ عمر إِ فِإن مجرده لازم }
$$

For the example in this sentence /farracha Zaidun 'Amran/ the first stem of the verb (mujarrad) /farrachal had the character of intransitive verb (lazim: does not need the object). But, after changing the pattern from lazim (intransitive) into muta'adi (transitive), the verb will need the object. The word / faracha/ intransitive, the meaning is "happy", but after we changed it into wazan fa'ala for transitive verb, the verb /faracha/ becomes /farracha/, the meaning is "to make somebody happy". Some of the data had been grabbed from this research, such as in the table 2 bellow (the transformation from the intransitive verb into transitive verb). 
Table 2. The Transformation From Transitive Verb Into Intransitive Verb

\begin{tabular}{|c|c|c|c|c|}
\hline No. & $\begin{array}{c}\text { The transitive verb } \\
\text { (the second stem) using the wazan } \\
\text { fa'-'ala (فَّ) }\end{array}$ & $\begin{array}{c}\text { The meaning in } \\
\text { Indonesian language } \\
\text { using the affixation } \\
(\mathrm{ME}-\mathrm{KAN})\end{array}$ & $\begin{array}{l}\text { The intransitive verb } \\
\text { (the first stem) }\end{array}$ & $\begin{array}{l}\text { The meaning in } \\
\text { Indonesian language } \\
\text { does not using the } \\
\text { affixation } \\
\text { (ME-KAN) }\end{array}$ \\
\hline 1 & صَحََحَ - يُصَنِِّح & membenarkan & 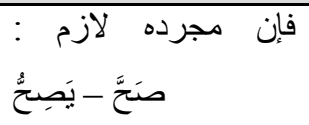 & Benar \\
\hline 2 & 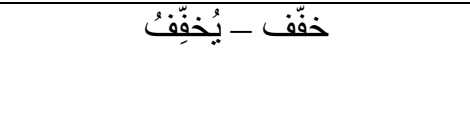 & meringankan & 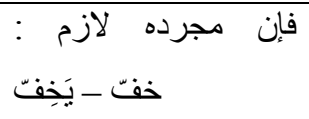 & Ringan \\
\hline 3 & جهُّل - يُجِقِّلُ & membodohkan & 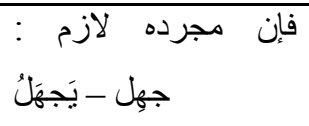 & Bodoh \\
\hline 4 & كَّر - يُكدرّ & mengeruhkan & 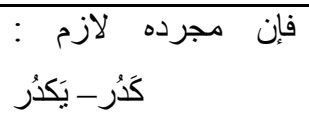 & Keruh \\
\hline 5 & حَزْن - يحزِّنُ & menyedihkan & 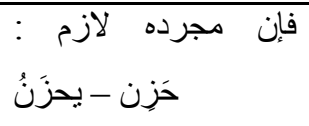 & Sedih \\
\hline
\end{tabular}

Antonym in every language dominantly comes from the adjective forms and very little amount of antonym which comes from the verb. This is the specific character of antonym based on Cruse (1986:204). Based on the table 2, we can look that the antonym aslo dominantly comes from the adjective meaning, such as: sedih, bodoh, keruh, ringan, benar, although the form is verb in Arabic language, because Arabic language has the verb that its meaning is for adjective forms. Thus, the data in this research will be dominant also by the antonym which had been coming from the adjective categories, despite the verb also had been entered to the data, for example: angguk, gadai, kawin, masuk, menang, ragu, risau, sedih, takut, tidur, etc.

Some of stems using in this research (nouns and verbs) are abai, aman, angguk,

Mengabaikan
Mengamankan $><$
Membedakan
Membekukan
Membenarkan
Memberatkan
Membesarkan
Mencukupkan
Menjauhkan
Memanaskan
Menyedihkan

bagus, beda, beku, benar, berat, besar, cerdas, cukup, gadai, jauh, jernih, jinak, kawin, kencang, kental, keras, kuat, lambat, lelah, lembab, lembut, lurus, masuk, menang, mulia, panas, pendek, ragu, risau, rugi, satu, sedih, sehat, sempit, sukar, tajam, takut, tampak, tidur, tinggi.

Furthermore, to get the antonym in the lexeme using the affixation "me-kan" by employing the distributional method, all of the stems had been added by the affixation of "me-kan" which is having the function to change the stems into the transitive verbs. The stems and the lexeme that had been added by the affixation "me-kan" will be contrasted and opposed with the appropriate of lexeme using the affixation "me-kan", until we will get the lexeme using the affixation "me-kan" with its pairs of antonym, such as in the example bellow.

$$
\begin{array}{ll}
>< & \text { Memperhatikan } \\
\multicolumn{2}{l}{\text { Mengacaukan }} \\
>< & \text { Menyamakan } \\
>< & \text { Mencairkan } \\
>< & \text { Menyalahkan } \\
>< & \text { Meringankan } \\
>< & \text { Memperkecil } \\
>< & \text { Mengurangi } \\
>< & \text { Mendekatkan } \\
>< & \text { Mendinginkan } \\
>< & \text { Menyenangkan }
\end{array}
$$


By using the method of distributional and the base technique of dividing the units of language directly (Metode agih), we will get the antonym in
Indonesian language and Arabic language, and also the lexeme using the affixation "me-kan" and its antonym, such as in the table 3 bellow.

Table 3. The List of Antonym and Lexeme Using the Affixation "Me-Kan"

\begin{tabular}{|c|c|c|c|c|c|}
\hline No. & The first stem & $\begin{array}{c}\text { Lexeme using the } \\
\text { affixation "ME- } \\
K A N \text { " }\end{array}$ & $\begin{array}{l}\text { The page in } \\
\text { Al-Munawnir }\end{array}$ & Antonym & $\begin{array}{l}\text { The page in } \\
\text { Al-Munawwir }\end{array}$ \\
\hline 1. & Abai & Mengabaikan & 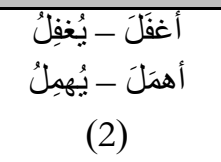 & Memperhatikan & 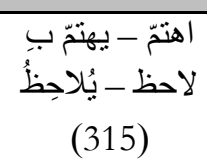 \\
\hline 2. & Aman & Mengamankan & 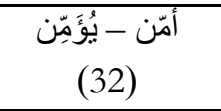 & Mengacaukan & شوّس (0) الأمر \\
\hline 3. & Angguk & $\begin{array}{l}\text { Menganggukkan } \\
\text { (kepala) }\end{array}$ & طأ طأر أسه & $\begin{array}{l}\text { Menggeleng } \\
\text { (kepala) }\end{array}$ & هزّ الر أس ـ يُحرّكَ \\
\hline 4. & Bagus & Membaguskan & أحسنَ - يُحسَنَ (79) & Menjelekkan & 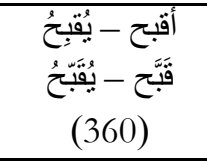 \\
\hline 5. & Beda & Membedakan & 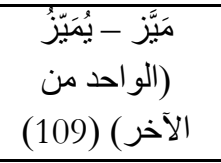 & Menyamakan & 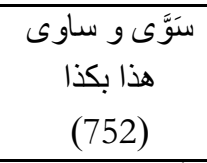 \\
\hline 6. & Beku & Membekukan & أجَمَّد - يُجَمّدُ & Mencairkan & 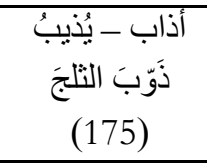 \\
\hline 7. & Benar & Membenarkan & 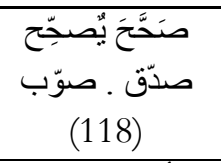 & Menyalahkan & 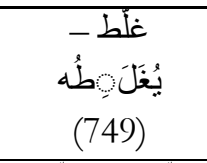 \\
\hline 8. & Berat & Memberatkan & 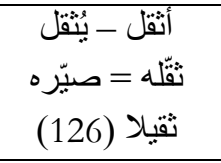 & Meringankan & خُفْف - يُخْفِّقُ \\
\hline 9. & Besar & Membesarkan & كَبر - & Memperkecil & صغنر - يُصَنَغِرْ \\
\hline 10. & Cerdas & Mencerdaskan & 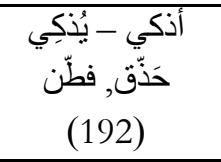 & Membodohkan & 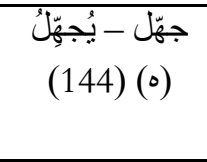 \\
\hline 11. & Cukup & Mencukupkan & كمّل - يُكمّلُ & Mengurangi & 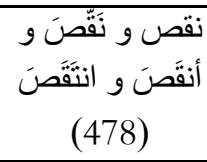 \\
\hline 12. & Gadai & Menggadaikan & 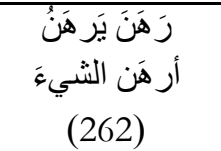 & Menebus & 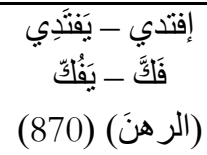 \\
\hline
\end{tabular}




\begin{tabular}{|c|c|c|c|c|c|}
\hline 13. & Jauh & Menjauhkan & بَبَّدَ و بَاعد يُبِعِدُ & Mendekatkan & 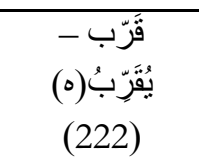 \\
\hline 14. & Jernih & Menjernihkan & صنُفَى - يُصَفَى & Mengeruhkan & 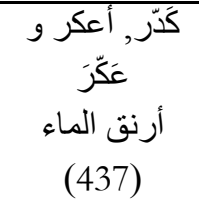 \\
\hline 15. & Jinak & Menjinakkan & 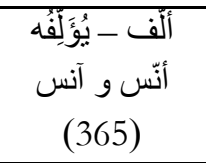 & Menjadi buas & 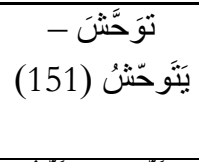 \\
\hline 16. & Kawin & Mengawinkan & أَنَحَ و زَوَّجَ & $\begin{array}{l}\text { Menceraikan } \\
\text { (suami-istri) }\end{array}$ & 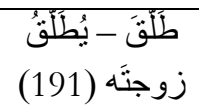 \\
\hline 17. & Kencang & Mengencangkan & 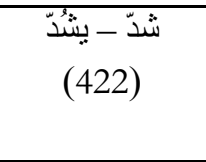 & Mengendurkan & أرخى - يُرْخَى \\
\hline 18. & Kental & Mengentalkan & خلُرَ و ألبنَ (423) & Mengencerkan & 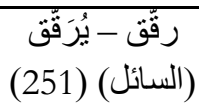 \\
\hline 19. & Keras & Mengeraskan & قُتّى و أقنسى (429) & Melunakkan & لَلَّنَ و لََلَّقَ \\
\hline 20. & Kuat & Menguatkan & قُوّي - يُوقِقِي & Melemahkan & 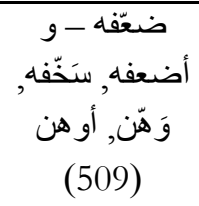 \\
\hline 21. & Lambat & Melambatkan & 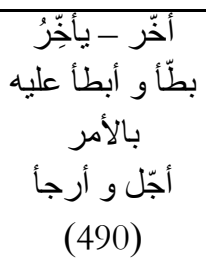 & Mempercepat & 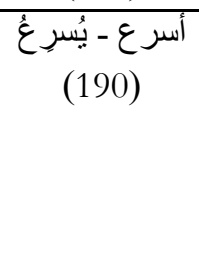 \\
\hline 22. & Lelah & Melelahkan & 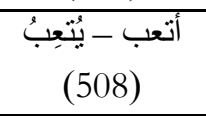 & Menyegarkan & 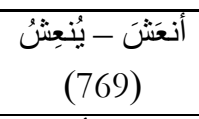 \\
\hline 23. & Lembab & Melembabkan & 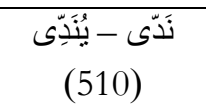 & Mengeringkan & يَبَِّ و أيبس (432) \\
\hline 24. & Lembut & Melembutkan & 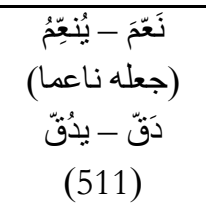 & $\begin{array}{l}\text { Menjadikan } \\
\text { Kasar }\end{array}$ & 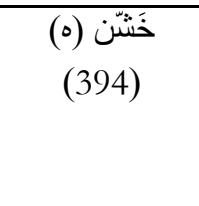 \\
\hline 25. & Lurus & Meluruskan & 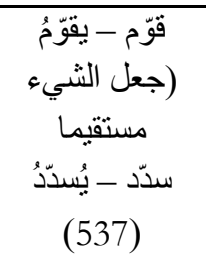 & Membengkokkan & عَوْج - يُعوِجُ \\
\hline 26. & Masuk & Memasukkan & 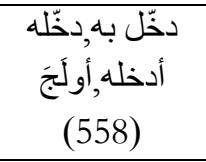 & Mengeluarkan & 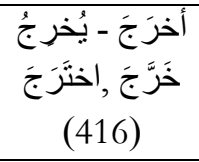 \\
\hline 27. & Menang & Memenangkan & فاز بِ & Mengalahkan & غلب - يغلبه أو \\
\hline
\end{tabular}




\begin{tabular}{|c|c|c|c|c|c|}
\hline & & \multicolumn{3}{|c|}{$(567)$} & \multirow{2}{*}{ 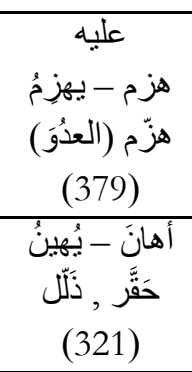 } \\
\hline 28. & Mulia & Memuliakan & 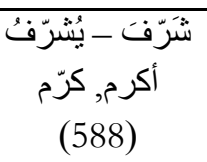 & Menghinakan & \\
\hline 29. & Panas & Memanaskan & 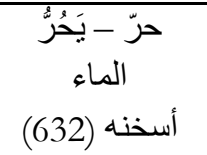 & Mendinginkan & و أبرَد - يُبَرِّدُد \\
\hline 30. & Pendek & Memendekkan & قصَّر - يقصَ & Memperpanjang & 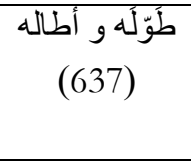 \\
\hline 31. & Ragu & Meragukan & 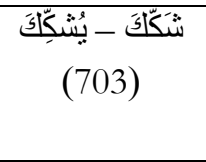 & Mempercayai & أمنّه و آمن به به به \\
\hline 32. & Risau & Merisaukan & أفجَعَ (730) وَجَعَ & Menenangkan & 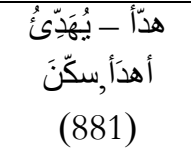 \\
\hline 33. & Rugi & Merugikan & خَسَرَ - يُخَسَرُ & Menguntungkan & $\begin{array}{c}\text { ربّح و أربَحهُ } \\
\text { (931) }\end{array}$ \\
\hline 34. & Satu & Menyatukan & 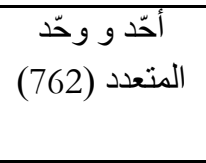 & Menceraiberaikan & فرّّق - يُفَّرَّق \\
\hline 35. & Sedih & Menyedihkan & حَزَّنَه (768) وَحَنَ & Menyenangkan & سرّر (أفرَحَ و فرّح \\
\hline 36. & Sehat & Menyehatkan & $\begin{array}{c}\text { أصنَحْ - يُصِحِّ } \\
\text { (770) }\end{array}$ & Menyakitkan & 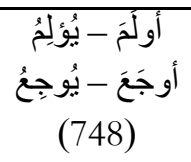 \\
\hline 37. & Sempit & Menyempitkan & 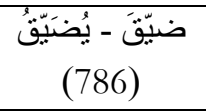 & $\begin{array}{l}\text { Meluaskan } \\
\text { (Memperluas) }\end{array}$ & 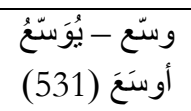 \\
\hline 38. & Sukar & $\begin{array}{l}\text { Menyukarkan } \\
\text { (Mempersukar) }\end{array}$ & 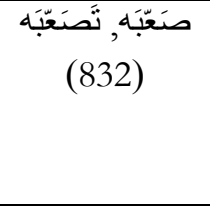 & Memudahkan & 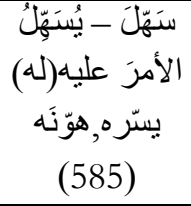 \\
\hline 39. & Tajam & Menajamkan & 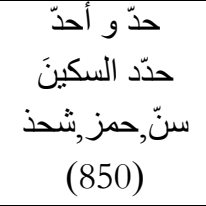 & Menumpulkan & (ألسلّ - يُكِكلُ3 \\
\hline 40. & Takut & Menakutkan & 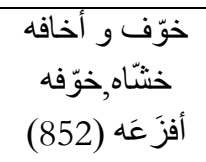 & $\begin{array}{l}\text { Memberanikan } \\
\text { (diri) }\end{array}$ & تَتَجِعرع (125) - يتجرَّأ \\
\hline 41. & Tampak & Menampakkan & 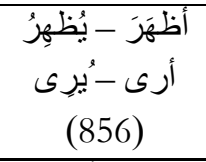 & Menyembunyikan & 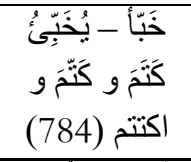 \\
\hline 42. & Tidur & Menidurkan & نَوَّمَ و أنَامَهَ & Membangunkan & أصحى فُلانا \\
\hline
\end{tabular}




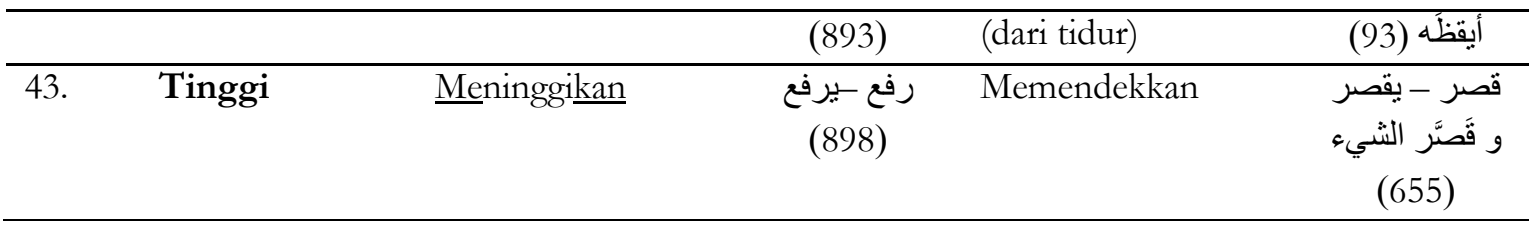

The dominant character of wazan

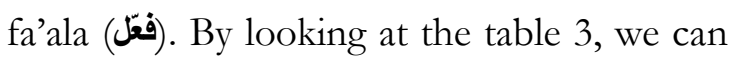
conclude that the measure/ wazan fa'-'a-la is very dominant in rendering the lexeme "me- kan" in Indonesian language. We can look at the table 4 as the derivative table from table 3 , to get the closer result about the dominant character of wazan fa'-'a-la.

Table 4. The List of Arabic Verbs using the Measure Fa'-'a-la (فقل)

\begin{tabular}{|c|c|c|}
\hline No & فقل Wazan & Leksem Me-Kan \\
\hline 1 & أمّن - يُوَََمِن & Mengamankan \\
\hline 2 & شُوّس - يُشوّش & Mengacaukan \\
\hline 3 & حسَّنَ - يُحسّن & Membaguskan \\
\hline 4 & فَفَبَّح - يُقَفَبْحُ & Menjelekkan \\
\hline 5 & مَيَّز - يُمَتِّزُ & Membedakan \\
\hline 6 & سَوَّى - يُسوّي & Menyamakan \\
\hline 7 & ذَّوَبَ - يُذْوَبُ & Mencairkan \\
\hline 8 & جَمَدْ - يُجَمَدُ & Membekukan \\
\hline 9 & صَحَّحَ - يُصحِّح & Membenarkan \\
\hline 10 & صدّق - يُصدِّق & Membenarkan \\
\hline 11 & صوّب - يُصوّبُ & Membenarkan \\
\hline 12 & غَلَط - يُغَلَط & Menyalahkan \\
\hline 13 & خفّة - يُخِفِّْ & Meringankan \\
\hline 14 & 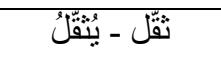 & Memberatkan \\
\hline 15 & كبّر - يُكبِّر & Membesarkan \\
\hline 16 & 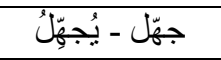 & Membodohkan \\
\hline 17 & حَذْق - يُحدِقُ & Mencerdaskan \\
\hline 18 & فَطنْ - يُفَطنُ & Mencerdaskan \\
\hline 19 & كمّل - يُكمّلُ & Mencukupkan \\
\hline 20 & بعدّد - يبيحّد & Menjauhkan \\
\hline 21 & قَرَّب - يُقَرَّبُبُ & Mendekatkan \\
\hline 22 & صفنى - يُصَفْى & Menjernihkan \\
\hline 23 & كَدّر - يُكدّر & Mengeruhkan \\
\hline 24 & عَكْرَ - يُعكّرَ & Mengeruhkan \\
\hline 25 & أَلْف - يُوَلَفْ & Menjinakkan \\
\hline 26 & أنَّس - يُأْنَس & $\underline{\text { Menjinakkan }}$ \\
\hline 27 & زوّج - يُزْوَجُ & Mengawinkan \\
\hline 28 & طَلْقَ - يُطلَفَقُ & Menceraikan (suami istri) \\
\hline 29 & 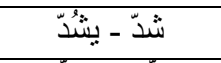 & Mengencangkan \\
\hline 30 & خَتُرَ - يختُرُ & Mengentalkan \\
\hline 31 & رَُقَق - يُرَفْق & Mengencerkan \\
\hline 32 & قَتَى - يُقَسِتِى & Mengeraskan \\
\hline 33 & 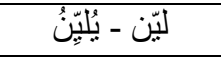 & Melunakkan \\
\hline
\end{tabular}




\begin{tabular}{|c|c|c|}
\hline 34 & قوّى - يُقِّى & Menguatkan \\
\hline 35 & ضعّف - يُضعِف & Melemahkan \\
\hline 36 & سَخْف - يسخْف & Melemahkan \\
\hline 37 & وَهَهْن - يُوْهُنُ & Melemahkan \\
\hline 38 & أخِّر - يُأْخّر & Melambatkan \\
\hline 39 & بطَاً - يبطُاً & Melambatkan \\
\hline 40 & ندّى - يندّى & Melembabkan \\
\hline 41 & يَيَس - يُيِيّسُ & Mengeringkan \\
\hline 42 & جَفْف - يجفُّف & Mengeringkan \\
\hline 43 & نعّم - ينعّم & Melembutkan \\
\hline 44 & دقّ - يدُقِّ & Melembutkan \\
\hline 45 & قوّم - يقوّم & Meluruskan \\
\hline 46 & سدّد - يسدّد & Meluruskan \\
\hline 47 & عوّج - يُعِوِجُ & Membengkokkan \\
\hline 48 & دخّل - يدخّل & Memasukkan \\
\hline 49 & خَرَّجَ - يخرّج & Mengeluarkan \\
\hline 50 & شُرَّنَ - يُشرَّنَ & Memuliakan \\
\hline 51 & كرّم - يكرّم & Memuliakan \\
\hline 52 & حَقٌر - يحقُرُ & Menghinakan \\
\hline 53 & ذَّلَّل - يذلَلْ & Menghinakan \\
\hline 54 & حرّ - يَحُرُ & Memanaskan \\
\hline 55 & برّد - يُيَرِّدد & Mendinginkan \\
\hline 56 & قصّرَ - يقصّر & Memendekkan \\
\hline 57 & 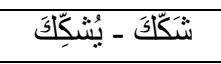 & Meragukan \\
\hline 58 & فَجَعَع - يفجّع & Merisaukan \\
\hline 59 & 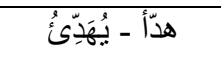 & Menenangkan \\
\hline 60 & سكَّنَ - يسكّنَ & Menenangkan \\
\hline 61 & خَسِرَ - يُخَسرُ & Merugikan \\
\hline 62 & ربّح - بربّح & Menguntungkan \\
\hline 63 & وحّد - يوحّد & Menyatukan \\
\hline 64 & فرّق - يُفرّق & $\underline{\text { Menceraiberaikan }}$ \\
\hline 65 & بدّد - يبيدّد & Menceraiberaikan \\
\hline 66 & شَتِت - يشتنّتُ & Menceraiberaikan \\
\hline 67 & حَزّن - يحزِّنُ & Menyedihkan \\
\hline 68 & فرّ ح - يفرّحُح & Menyenangkan \\
\hline 69 & سرّر - يسرّر & Menyenangkan \\
\hline 70 & ضيَقِ - يُضَنَقِقُ & Menyempitkan \\
\hline 71 & وستّع - يُوَستَعُع & Meluaskan \\
\hline 72 & صَعَبَ - يصعَب & Menyukarkan \\
\hline 73 & 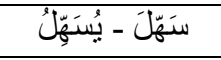 & Memudahkan \\
\hline 74 & يسّر - يُيَسَّر & Memudahkan \\
\hline 75 & هوَّنَ - يهوّن & Memudahkan \\
\hline 76 & حدّد - يحدّد & Menajamkan \\
\hline 77 & خوّف - يخوّف & Menakutkan \\
\hline 78 & 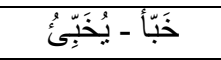 & Menyembunyikan \\
\hline 79 & كَنَّة - يُكتّم & Menyembunyikan \\
\hline
\end{tabular}




\begin{tabular}{lll}
\hline 80 & Menidurkan \\
\hline 81 & $\underline{\text { Memendekkan }}$ \\
\hline
\end{tabular}

Table 4 shows that there are 81 words using wazan fa'ala which had been translated using the transitive form with the affixation "me-kan". This study also shows that the prefix Men- movement has a very broad and productive in Indonesian. The same study ever conducted also about prefixes 'Men-' which examines the topic unergative and unaccusative (Nomoto and Soh, 2009a; 2009b; 2011). Studies on anatomy is also giving out new repertoire in researching prefix profound Indonesian or Malay language.

\section{CONCLUSION}

Generally, the antonym has a definition as a semantic correlation between speech units which has the meaning of inverse, opposite, or contrast between one and the others. For example the word "bad" has the antonym of the word "good", the word "live" has the opposite meaning with the word "death", the word "student" has the inverse with the word "teacher". And also the word "buy" has the contras with the word "sell". If we look at the Arabic language, we can find the concept of antonym in badi', such as: in aththibaq and al-muqabalah.

The data in this research was taken from the Indonesian - Arabic dictionary, AlMunawwir (2007). Dominantly, the data of lexeme using the affixation "me-kan" in $\mathrm{Al}$ Munawwir dictionary had been translated into Arabic language using the wazan fa'- ' $a$-la. Thus, the affixation of "ME-KAN" in Indonesian language is extremely equivalent with wazan fa'-'a-la in Arabic language. Wazan is the measure of the pattern in Arabic trilateral verbs. The affixation of "ME-KAN" in Indonesian language has the function to form the transitive verb, and also wazan $f a$ ' ' $a$-la in Arabic language has the same function for ta'diyyah (to form the verb from intransitive into transitive). So that, wazan fa'-'a-la is one of the dominant measures to give the meaning of lexeme using the affixation "ME-KAN" inside the process of forming the transitive verb in Indonesian language.

\section{REFERENCES}

Anggraeni, S. (2015). Antonim dalam Bahasa Jawa: Suatu Kajian Semantik. Surakarta: Sebelas Maret University

Anis, M. Y. (2015).Pengembangan tema dalam buku Al-Qira'ah Ar-Rasyidah sebagai pondasi awal dalam latihan menulis kreatif bahasa Arab. Jurnal Arabiyat 2(2), pp. 1-10.

Anis, M. Y. (2014). Konstruksi tema rema judul berita dalam surat kabar Alahram: Analisis sintaksis. Lisania Jurnal Ilmu dan Pendidikan Babasa Arab, V(2), pp. 245-264.

Anis, M. Y. (2013). Humor dan komedi dalam sebuah kilas balik sejarah sastra Arab. CMES (Center of Middle Eastern Studies) Jurnal Studi Timur Tengah. VI(2): pp. 199-209.

Anis, M.Y. (2010). Analisis semantik kata kerja "datang" di dalam bahasa Arab. CMES (Center of Middle Eastern Studies) Jurnal Studi Timur Tengah. I(3): pp. 292-302.

Anis, M.Y., Arifuddin, \& Farhah, E. (2015). Bahan Ajar: Panduan Menulis Kreatif Bahasa Arab: Pengembangan Tema dalam Buku Al-Qira'ah Ar-Rasyidah. Surakarta: Penerbit Program Studi Sastra Arab UNS.

Becker, C.A.(1980). Semantic context effects in visual word recognition: An analysis of semantic strategies. Memory \& Cognition. 8(6): pp.493-512

Chaer, A. (2003). Linguistik Umum. Jakarta: PT Rineka Cipta.

Cruse, D.A. (1986). Lexical Semantics. Cambridge: CambridgeUniversity Press.

Depudyt, L. (1997). Agent-less indirect adjectival forms in Egyptian and Arabic: The case of jrrw n.f and maful lahu "for whom one acts". 
Journal of the American Oriental Society. 117(3), pp. 487-505.

Fromkin, V., \& Rodman, R. (1998). An Introduction to Language. (6thEdition). Orlando: Harcourt Brace College Publishers.

Husnaini, S $\}$ ala $>$ h $\}$ ud-di $>$ n Sa $>$ lih $\}$. (2005). Ad-Dala>lah wan-Nab\}wu. Tauzi>'u Maktabatil-A $>$ da $>$ b.

Ikrarini, E. O., \& Wijana, I. D. P. (2012). Tipe-Tipe Antonimi Bahasa Inggris Menurut Sifat Pertentangan Maknanya: Kajian Relasi Semantis. Yogyakarta: Universitas Gadjah Mada.

Kostić, N. (2015). Antonym sequence in written discourse: A corpus-based study. Language Sciences. 47(1), pp. 1831

Kostić, N. (2011). .Antonymous frameworks in Serbian written discourse: Phrasal contexts of antonym co-occurrence in text. Poznan Studies in Contemporary Linguistics. 47(3), pp.509-537

Lyons, J. (1995). Pengantar Teori Linguistik. Jakarta: PT Gramedia Pustaka Utama.

Nomoto, H., \& Soh, H.L. (2009a). Movement across meN- and unaccusatives in Malay.The $83 \mathrm{rd}$ Annual Meeting of the Linguistic Society of America 8-11 January 2009, San Francisco, CA

Nomoto, H., \& Soh, H.L.(2009b). The Verbal Prefix Men-and The Unergative.The13th

International Symposiumon MalayIndonesian Linguistics (ISMIL) 6-7 June 2009, Lombok, Indonesia

Munawwir, A.W. (2007). Kamus Al Munawnir Indonesia Arab Terlengkap. Surabaya. Pustaka Progresif.
Pamungkas. (1994). Inti Sari Kata Bahasa Indonesia. Surabaya: Apollo.

Richards, J.C., \& Schmidt, R. (2007). Longman Dictionary of Language Teaching and Applied Linguistics. London: Longman Group.

Saddhono, K. (2015). Sociopragmatic approach on discourse structure of friday prayer's sermon in java and madura island. Journal of Languageand Literature. 6(1), pp.26-29

Sasangka, S. S. T. W. (2004). Keantoniman dalam Babasa Jawa. Jakarta: Universitas Negeri Jakarta.

Schramm, G.M. (1962). An outline of classical Arabic verb strucutre. Source: Language, 38(4),pp. 360-375.

Sudaryanto. (1993). Metode dan Aneka Teknik Analisis Bahasa: Pengantar Penelitian Wahana Kebudayaan secara Linguistis. Yogyakarta: Duta Wacana University Press.

Susanti, R., Aminah, S., \& Oktaviani, N. (2009). Sinonim, Repetisi, dan Antonim dalam Bahasa Jepang: Telaah Majalah Nihongo Journal dan Hiragana Times. Lingua Cultura, 3(1),pp. 85-98

\section{ACKNOWLEDGMENTS}

We would like to express our sincere thankfulness to those who has helped this research and to the editors of Jurnal Pendidikan Bahasa dan Sastra Universitas Pendidikan Indonesia for this research publication. 